\title{
Islamic Banking in Nigeria: A Stimulant for Mobilising Funds for Productive Activities
}

\author{
Yekini Olawaiye Lawal (Ph.D. Business Administration) \\ Provost, College of Social and Management Sciences, Afe Babalola University, Ado Ekiti, \\ Nigeria. GSM +2348033562682; Email: lawal9250@yahoo.com
}

\begin{abstract}
Islamic Banking is not synonymous with interest free banking. It operates on Islamic code of ethics which is based on the Quran. All its funds are asset backed. This makes its entire funds available for investment in the production of goods and services. Islamic banking forbids investment in all economic activities that are socially or morally injurious to the society. It operates on profit and loss sharing motive. Islamic banking was formally introduced into the Nigerian banking industry effective $13^{\text {th }}$ January, 2012. The introduction generated a lot of controversies. This work examined the problems, challenges and prospects of the new model. It was found that most Nigerians lacked the knowledge of the model and its operations, hence the controversies. The study found that Islamic banking had taken root in many Western countries. The non-interest regime and its ethical principles offered veritable incentives and attractive options for investors. In spite of the controversies and the initial challenges, Islamic banking is suitable for funding entrepreneurship and economic development in the real sector of the Nigerian economy as it provides easy access to cheap source of funds.
\end{abstract}

Keywords: Haram, Takaful, Jihad, Sukuk and Mudaraba

\section{INTRODUCTION}

Islamic Banking: Islamic Banking has been described as a system of banking that is consistent with the principles of Islamic law (Shariah) and its application through the development of Islamic economics (Lawal, 2010). Lawal enumerated the most important features of Islamic Banking to include: the abhorrence of interest rate, gambling, consumption or transactions in alcohol, pornography, all economic activities that are socially or morally injurious to the society and all items deemed forbidden by Shariah (haram). Islamic banking operates on profit and loss sharing between the providers of funds (investors) and the user of the funds (entrepreneur).

According to an International Monetary Fund report (IMF, 2010), Islamic finance is one of the fastest growing segments of the global financial industry. The report noted that, Islamic finance in some countries had become systematically important and, in many others, it had become too big to be ignored. An International Monetary Fund paper authored by Sole (2007) noted that as at 2007, apart from the 250 mutual funds that complied with Islamic principles, more than 300 Islamic financial institutions existed globally, which were spread across 51 countries. The report added that the industry had experienced growth rates of $10-15 \%$ over a decade, a trend which was expected to continue. Islamic banking has evolved into a whole new world of Islamic finance which also includes insurance (Takaful), Islamic fixed income instruments (Sukuk), Islamic asset management, among others.

Evolution of Islamic Banking in Nigeria: The process of the introduction of non-interest banking in Nigeria began with the amendment to the Banks and Other Financial Institutions Act, (BOFIA, 1991). Section 39(1a) of the act stated as follows:
"...that "except with the written consent of the Governor, no bank shall, as from the commencement of this Decree, be registered or incorporated with a name which includes the words "Central" "Federal," Federation, "National", "Nigeria", "Reserve", "State", "Christian", "Islamic", "Moslem", "quranic", or "biblical" ; in review of the banks and other financial institutions [BOFI] act 1991 as amended."

By the provisions of the Act, the establishment of Islamic banking in Nigeria by the Governor of the 
CBN, who was the consenting authority, was legal and absolutely constitutional. Relying on the act, Habib Bank applied for and got the Central Bank of Nigeria's (CBN) approval to set up an Islamic banking window in 1996. Some other insurance companies introduced alternative insurance products, based on Islamic principles. It was called "Takaful". In 2004, the Jaiz International Bank applied to the Central Bank of Nigeria (CBN) to set up a full fledged non-interest bank that was based on Islamic principles. It got the approval in principle in 2005 but could not commence operation because of its inability to meet the CBN capital requirement of twenty five billion naira.

In response to the increasing number of investors, banks and other financial institutions desiring to offer non-interest products and services, the CBN developed a draft framework for the regulation and supervision of non-interest banks in Nigeria. According to (Eke, 2009), the document was issued as an exposure draft for comments, suggestions or inputs by stakeholders. The guidelines were issued pursuant to Section 28 (1)(b) of the CBN Act, (2007) and the following provisions of BOFIA (1991) (as amended): Sections 55(2); 52; 59(1)(a); 32(1); 61; 23(1). The guidelines were to be read together with the BOFIA, (1991) (as amended), the CBN Act (2007) and circulars/guidelines issued by the CBN from time to time.

The guidelines required all licensed banks or promoters wishing to offer non-interest banking products and services to operate, using any of the following models:

- Full-fledged non-interest bank or subsidiary which should be licensed in accordance with the current guidelines for licensing of banks issued by the CBN.

- Non-interest banking branch of a conventional bank or non-interest banking branches which could be established in line with extant $\mathrm{CBN}$ regulation on bank branch expansion.

- Non-interest banking window of a conventional bank.

It directed all non-interest banks to transact business using any of the Islamic financial instruments such as: Murabaha, Mudarabah, Musharakah, ljarah, Salam, Istisna and Sukuk.

Paragraph 7 of the guidelines, subtitled Corporate Governance required that all licensed banks offering Shariah-compliant financial products or services should have a Shariah compliant review mechanism and a Bank Shariah Advisory Committee (SAC) as part of their governance structure. The release of the guidelines generated a lot of controversies. In reaction to the controversies, the Central Bank of Nigeria issued other guidelines that superseded the earlier one. Though, the new guidelines restated that, section 23 (1) and section 66 of the BOFIA, (1991) (as amended) explicitly provided for the licensing of Non-Interest Banks (NIBs), it removed the restriction of non-interest banking to Islamic banking. It added other forms of non-interest banking that is not based on Islamic principles (Abdullahi, 2011). Another significant review was the replacement of the Sharia Council with the Advisory Council of Experts, whose responsibility would be to advise the CBN on the appropriateness of relevant financial products to be offered by the institutions.

In spite of the amendments to the old guidelines, the introduction of non interest banking continued to generate a lot of controversies among Nigerians (Solagbade, 2011). The controversies had polarized the populace, on the concept and motives of the new scheme. The objective of this work was to examine these controversies, identify the problems and prospects of the model and determine how the model could be used as a means to mobilizing cheap funds for the productive sector of the Nigeria Economy.

METHODOLOGY: Structured questionnaires were administered to three groups of respondents. The three groups were: those working in the banks, who would be expected to operate the model; the civil servants who make policies and the university lecturers who are the elites who by virtue of the profession are required to posses general knowledge for dissemination to the public. One hundred respondents were randomly interviewed. Seventy four bank officers, eighty university lecturers and ninety eight civil servants responded. Data were also collected from primary and secondary sources. A Google alert line was also opened to receive real time information on the latest developments in the global Islamic banking and finance industry. Descriptive statistic was used to present the data.

FINDINGS AND DISCUSSIONS: The findings were presented and discussed under the below listed headings. They were illustrated with tables 1 to 8 . 
Table 1: Level of knowledge of the workings of the Islamic Banking model

\begin{tabular}{|l|c|c|c|}
\hline & Good & Little & None \\
\hline Lecturers & 20 & 58 & 22 \\
\hline $\begin{array}{l}\text { Civil } \\
\text { Servants }\end{array}$ & 5 & 35 & 60 \\
\hline Banker & 35 & 36 & 29 \\
\hline Average & 20 & 42 & 37 \\
\hline
\end{tabular}

Table 2: Islamic Bank is synonymous with Interest free banking

\begin{tabular}{|l|l|l|l|l|}
\hline & $\begin{array}{l}\text { Strongly } \\
\text { Agree }\end{array}$ & Agree & $\begin{array}{l}\text { Do not } \\
\text { Agree }\end{array}$ & $\begin{array}{l}\text { Don't } \\
\text { Know }\end{array}$ \\
\hline Lecturers & 59 & 12 & 20 & 9 \\
\hline $\begin{array}{l}\text { Civil } \\
\text { Servants }\end{array}$ & 14 & 27 & 6 & 53 \\
\hline Banker & 58 & 22 & 8 & 12 \\
\hline Average & 44 & 20 & 11 & 25 \\
\hline
\end{tabular}

Table 3: Islamic Bank model violates the Nigerian constitution

\begin{tabular}{|l|l|l|l|l|}
\hline & $\begin{array}{l}\text { Strongly } \\
\text { Agree }\end{array}$ & Agree & $\begin{array}{l}\text { Do not } \\
\text { Agree }\end{array}$ & $\begin{array}{l}\text { Don't } \\
\text { Know }\end{array}$ \\
\hline Lecturers & 10 & 15 & 43 & 32 \\
\hline $\begin{array}{l}\text { Civil } \\
\text { Servants }\end{array}$ & 6 & 27 & 15 & 42 \\
\hline Banker & 12 & 21 & 46 & 21 \\
\hline Average & 9 & 21 & 35 & 32 \\
\hline
\end{tabular}

Table 4: Islamic Banking model is to promote Jihad

\begin{tabular}{|l|l|l|l|l|}
\hline & $\begin{array}{l}\text { Strongly } \\
\text { Agree }\end{array}$ & Agree & $\begin{array}{l}\text { Do not } \\
\text { Agree }\end{array}$ & $\begin{array}{l}\text { Don't } \\
\text { Know }\end{array}$ \\
\hline Lecturers & 28 & 22 & 34 & 6 \\
\hline $\begin{array}{l}\text { Civil } \\
\text { Servants }\end{array}$ & 16 & 12 & 57 & 15 \\
\hline Banker & 12 & 18 & 50 & 20 \\
\hline Average & 17 & 17 & 30 & 14 \\
\hline
\end{tabular}

Table 5: Profits from Islamic Banking model may be used to fund terrorism

\begin{tabular}{|l|l|l|l|l|}
\hline & $\begin{array}{l}\text { Strongly } \\
\text { Agree }\end{array}$ & Agree & $\begin{array}{l}\text { Do not } \\
\text { Agree }\end{array}$ & $\begin{array}{l}\text { Don't } \\
\text { Know }\end{array}$ \\
\hline Lecturers & 22 & 56 & 22 & 0 \\
\hline $\begin{array}{l}\text { Civil } \\
\text { Servants }\end{array}$ & 14 & 28 & 42 & 6 \\
\hline Banker & 8 & 18 & 64 & 10 \\
\hline Average & 15 & 34 & 43 & 5 \\
\hline
\end{tabular}

Table 6: Islamic Banking model is to promote expansion of Islam

\begin{tabular}{|l|l|l|l|l|}
\hline & $\begin{array}{l}\text { Strongly } \\
\text { Agree }\end{array}$ & Agree & $\begin{array}{l}\text { Do not } \\
\text { Agree }\end{array}$ & $\begin{array}{l}\text { Don't } \\
\text { Know }\end{array}$ \\
\hline Lecturers & 28 & 22 & 34 & 6 \\
\hline $\begin{array}{l}\text { Civil } \\
\text { Servants }\end{array}$ & 16 & 12 & 57 & 15 \\
\hline Banker & 12 & 18 & 50 & 20 \\
\hline Average & 19 & 17 & 47 & 14 \\
\hline
\end{tabular}

Table 7: Islamic Banking model may not be profitable since no interest is charged

\begin{tabular}{|l|l|l|l|l|}
\hline & $\begin{array}{l}\text { Strongly } \\
\text { Agree }\end{array}$ & Agree & $\begin{array}{l}\text { Do not } \\
\text { Agree }\end{array}$ & $\begin{array}{l}\text { Don't } \\
\text { Know }\end{array}$ \\
\hline Lecturers & 34 & 45 & 15 & 18 \\
\hline $\begin{array}{l}\text { Civil } \\
\text { Servants }\end{array}$ & 40 & 38 & 8 & 14 \\
\hline Banker & 8 & 14 & 46 & 32 \\
\hline Average & 27 & 32 & 23 & 21 \\
\hline
\end{tabular}

Table 8: Islamic Banking model may not be viable

\begin{tabular}{|l|l|l|l|l|}
\hline & $\begin{array}{l}\text { Strongly } \\
\text { Agree }\end{array}$ & Agree & $\begin{array}{l}\text { Do not } \\
\text { Agree }\end{array}$ & $\begin{array}{l}\text { Don't } \\
\text { Know }\end{array}$ \\
\hline Lecturers & 56 & 25 & 15 & 4 \\
\hline $\begin{array}{l}\text { Civil } \\
\text { Servants }\end{array}$ & 40 & 38 & 8 & 14 \\
\hline Banker & 46 & 32 & 14 & 8 \\
\hline Average & 47 & 32 & 12 & 9 \\
\hline
\end{tabular}


Knowledge of Islamic Banking and Finance: Some of the controversies arose for the following reasons:

- lack of understanding of the clear ideology of Islamic Banking by the public

- lack of understanding of the workings of the system

- lack of sufficient mobilization, scarcity of trained, qualified and committed, Muslim managers with knowledge of Shariah and Banking.

Seventy one percent of the bankers agreed that they had some knowledge of the model. Yet, eighty eight percent of them agreed that Islamic banking was synonymous with non interest banking. Forty percent of the civil servants agreed that, they had some knowledge of the model. Forty one of them agreed that Islamic banking was synonymous with non interest banking. Seventy eight percent of the university lecturers agreed that they had some knowledge of the model. Seventy one percent of them agreed that Islamic banking was synonymous with non interest banking (See tables 1 and 2).

Islamic banking is not synonymous to non interest banking. Prohibition of interest is just a part. Islamic banking is ethical banking which abhors interest, investment in gambling, consumption or transactions in alcohol, pornography, all economic activities that are socially or morally injurious to the society. All its invested funds are tied to tangible assets (asset backed). The funds are therefore involved in productive activities.

Constitutional issue: Summarized below are the arguments of people on the constitutionality of the establishment of the model.

- that, the model violates the rights of Nigerian to freely engage in economic activities, contrary to section $16(1)(d)$ of the 1999 Constitution

- that, the inclusion of the word Islamic violated section 39(1) of the BOFIA which forbade a bank with a name or names with religious undertones

- that, the establishment of the CBN Shariah Council contravened the Federal Character Principle as entrenched in section 14(3) of the Nigerian constitution.

- that, Islamic Banking contravened the secularity of Nigerian as enshrined in section 10 of the constitution (Oriloye, 2011).

Thirty percent of the respondents agreed that the established model was unconstitutional. While thirty two percent did not know. Thirty five percent of them agreed that, it was constitutional as the CBN governor only exercised his constitutional authority. Section 39(1a) of the Banks and Other Financial Institutions Act, (BOFIA, 1991) as amended was unambiguous. It gave the consenting power to the Governor to enable a bank to be registered or incorporated with a name which included "Islamic" amongst others. The Federal Government of Nigeria by statute has put in place two separate pilgrims' welfare boards; Muslim and Christian boards, the members of which were made up of only Muslims and Christians respectively. The governments had for many years been sponsoring both Christians and Muslims for pilgrimages. The government by statute also has in place, the Shariah courts up to the appellate level. The CBN can therefore not be culpable for violating any of the following: the rights of Nigerians to freedom of commerce; the Federal character principle or the secularity of Nigerian. Those raising constitutional issues were simply sentimental and emotional.

\section{Linkage with Jihad (holy wars) and Terrorism Funding: $\quad$ There arose the fear that:}

- the model was designed to attract revenues with which to promote the expansion of Islam and prosecute jihad (holy wars) (Kern, 2011)

- the model is associated with Islamic fundamentalism for financing of terrorism

Thirty four percent of respondents expressed fear that, the model could be used to promote jihad. Forty nine percent opined that funds from the model could be used to fund terrorism if not properly monitored. Islamic banking arouses fear because it is associated with religious fundamentalism and financing of terrorism (Tables 4 and 5). With the Islamic fundamentalists attack of September 11, 2001, many Americans became wary of the Islamic banking model. Even the CBN had denied a group in the 1990s, the approval of license to establish an AP Qaeda Bank in Nigeria (Ujah, 2011). Although it could not be established, the speculation was strong that, the rejection could have been influenced by the name "AP Qaeda" among others.

Promotion of expansion of Islam: Many Christians expressed the fear that: 
- the model could be used to attract great revenues with which to promote expansion of Islam

- the model is a political strategy to legitimize and institutionalize Shariah law which was diametrically opposed to Western values

- the introduction was a ploy to shield Muslim communities in the West from the main stream society and to create Islamic parallel societies that is controlled by Shariah in the Western countries

Seventy five per of the Christian respondents agree that, the model could not make them to change their religious faith, since nobody could compel them to use the bank even though, they all agreed that, their religion equally forbade interest. The allegation that Sanusi Lamido Sanusi, the current governor of the CBN, who is a northern Muslim introduced the Islamic model of Banking as a move to Islamize Nigeria was not true. since Chukwuma Soludo who was the immediate past governor of $\mathrm{CBN}$ and a southern Christian, initiated the drafting of the original framework for the operation of Islamic banking system (Kandi, 2010).

Profitability: Fifty nine percent of the respondents were sure the profitability of the model if it would not charge interests on its funds. They wondered then, where its revenue would come from. While twenty three agreed that the model would be profitable, twenty one percent were not sure. In spite uncertainty on its profitability, forty percent of the respondents agreed to use the bank, if the model would provide them easy access to cheap funds, and thatt, becoming a Muslim would not be a precondition.

The International Monetary Fund (IMF) revealed that Islamic banks were more profitable than their conventional peers in the run up to the global economic crisis during the period, 2005 and 2007 (IMF, 2009). The report added that, the profit sharing policy of the model made its profitability to be less volatile over the cycle. Since all the funds of the model are asset backed, there would be no idle fund. All the funds would have been invested in the production of goods and services

Viability: Seventy nine percent of all the respondents and seventy eight percent of the bankers were of the view that, the model would not work in Nigeria, considering the high level of corruption and the low level of the integrity of the
Nigerian bank financiers. Fraud, moral hazard, interest rates and lack of transparency were among the factors identified by Latter (1997) as the causes of the global banking crises. According to Chibuike (2001), a survey by the country's banking regulator showed that, Nigerian banks have seen almost $\$ 10 \mathrm{~m}$ disappeared through employee fraud in 2002.

Unlike the conventional banks, Islamic banking places emphasis on trust (Amana), socially responsible investments, ethical and moral values. in a 2009 publication, Losservatore Romano, Pope Benedict XVI was reported to have given his support and suggested that, conventional banks, could regain client's trust by adopting the ethical principles that form the cornerstone of Islamic finance. The pope advised the conventional banks to look at the rules of Islamic Finance to restore confidence amongst their clients at a time of global economic crisis. (Anon,2009)

Sharia compliant products: The following doubts were expressed if the bank could truly deal with purely Sharia compliant products.

- the mixture of the funds of the Sharia compliant products and the conventional products

- the view by some scholars that Islamic banking truly rarely meets vital Shariah objectives

The provision of a mixture of Islamic products with the products of conventional banking was described by some Muslims as windows that provided prayer rooms for Muslims in the temples of non-believers (Bangudu, 2010). No bank that involves payment of interest can ever comply with the Sharia.

\section{Advancement of Islamic Banking in the Global Economy}

Although, the Gulf region is the largest Islamic finance market, the Western economy is fast turning into a major market.

Table 9: Islamic Banks in Western Countries and Offshore Centres as at end of 2009.

Source: Adapted from the CityUK Islamic Finance Report 2011

\begin{tabular}{|l|l|}
\hline Countries & Number of Banks \\
\hline United Kingdom & 22 \\
\hline United States & 10 \\
\hline
\end{tabular}




\begin{tabular}{|l|l|}
\hline Australia & 4 \\
\hline Switzerland & 4 \\
\hline France & 3 \\
\hline Canada & 1 \\
\hline Cayman & 1 \\
\hline Germany & 1 \\
\hline Ireland & 1 \\
\hline Luzenburg & 1 \\
\hline Russia & 1 \\
\hline
\end{tabular}

The Islamic finance industry is valued at $\$ 1.14$ trillion and growing at a rate of $10 \%$ a year (GIFR, 2011). Islamic banking had taken root in many Western countries and is growing faster in Britain, and in France than it is in many Islamic countries in the Middle East and Asia (Kern, 2011). The UK had continued to make increasing contribution to the development of Islamic finance education and skills (Phillips, 2012). Phillips observed that Islamic finance also had a crucial role to play in infrastructure development in the UK.

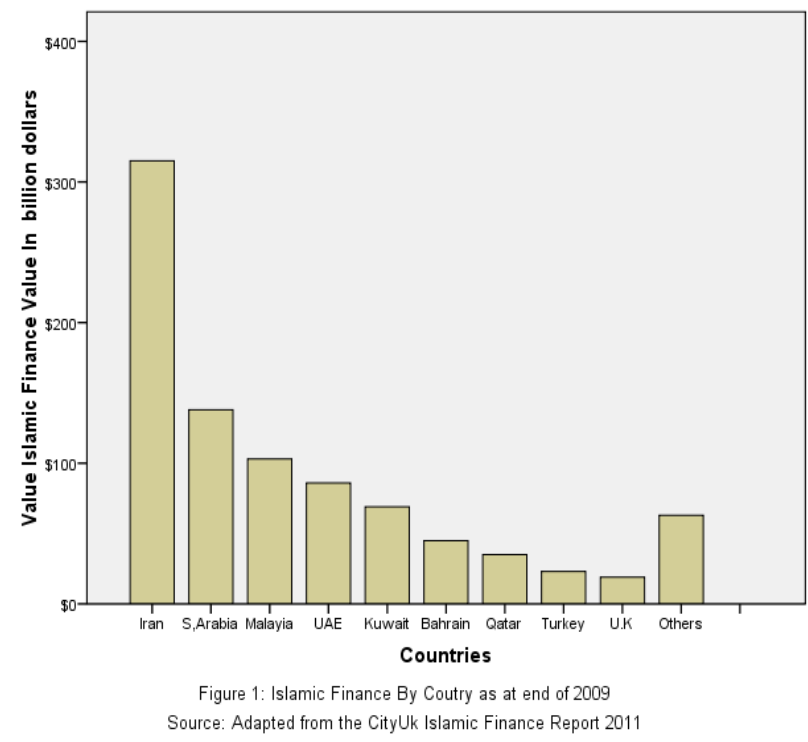

In France, Paris Europlace had also established an Islamic Finance Commission in December 2007, which was similar to the Islamic Finance Committee in the UK Trade and Investment (UKTI) (Parker,
2012). France has since implemented a series of tax and legislative changes to boost the Islamic Finance sector (Kern, 2011).

South Africa which is a predominantly western environment had legally established Islamic banking in South Africa which is regulated by the Board of Shariah Advisors. (Anon, 2012). The bank has both Muslim and non-Muslim clientele. According to the report, the interest from non Muslim patrons arose from the better proposition regarding asset financing.

In preparation for proper integration of the model into the German system, the legislators had commenced legislating on putting in place the rules of Islamic law in funding and respect for the prohibition of interest (Faleel, 2010). The country's banking regulator, the Federal Financial Services Authority had issued banking license to Kuveyt Turk Participation Bank, one of Turkey's four participation (Islamic) banks. The Chairman of the Coordination Council of the CIS Financial \& Banking Council (FBC) had been reported to indicate intention of the Council to seek to establish Islamic banks in Russia and Azerbaijan (Kzakov,2011).

The Swiss authorities had in 2006, granted a banking license to Faisal Private Bank to provide financial solutions that were based on ethics derived from Shriah (Belien,2006). Similarly, the Instituto de Empresa Business School in March 2009, launched the Centre for Islamic Economics and Finance (CIEF) with the objective of promoting Islamic Banking and Finance in Spain and other European countries and to let people know about the ethical financial system (Kern,2011).

\section{RECOMMENDATION}

- Section 39(1a) of the Banks and Other Financial Institutions Act, (BOFIA, 1991) as amended was unambiguous. It gave the Governor of CBN the consenting authority to enable a bank to be registered or incorporated with a name which included "Islamic" amongst others. Those raising constitutional issue were simply sentimental and emotional. Nigerians should drop sentiment and embrace the new banking product on its merit, exactly as it was stated in the original guidelines.

- Islamic Banking is not synonymous with interest free banking, although abhorrence of interest is part of it. Islamic banking model operates on Islamic code of ethics which is 
based on the Quran and the Shariah jurisprudence. Therefore, it should be properly named as Islamic banking as it is known in the Western countries and not simply non interest banking.

- The Financial accounting framework in Islamic Banking is different from that of the conventional banking. CBN should constitute the Shariah Advisory Committee (SAC) to regulate the operations of the bank.

- The non-interest regime offers veritable incentives and attractive options for investors. Investors particularly the cooperatives and small and medium enterprise should take advantage of its financing models of any of the following: project financing, joint trading, equipment leasing or partnership with profit sharing. Obtaining funds do not subject investors to the rigours of collateral that is usually demanded by the conventional banks as all transactions are based on moral ethics and trust,

- The Central Banking should make available to practitioners the standards set by the Accounting and Auditing Organisation for Islamic Financial Institution (AAOIFI) and apply them as much as possible.

- The Nigerian public should be sensitized to accept the model as an alternative method of financing which is ethically, morally and more profitable to the conventional method.

- Nigerian should take advantage of its membership of the Islamic Development Bank (IDD) Group to avail it the opportunity of alternative sources of funding especially for infrastructural development.

- Nigeria should review its banking law to accommodate this model as other Western countries have. Countries such as UK, France and Hongkong have changed their state laws to make them compliant with Shariah Law (Muhammad, 2012).

CONCLUSION: Islamic Banking is not synonymous with interest free banking, although abhorrence of interest is part of it. Islamic banking model operates on Islamic code of ethics which is based on the Quran and the Shariah jurisprudence. Islamic banking involves investing but not lending. The profit sharing policy of the model makes its profitability to be less volatile over the cycle. Since all the funds of the model are asset backed, there would be no idle fund. All the funds would have been invested in the production of goods and services

Islamic banking is both ethically and profitably motivated. Its ethics forbids greed, excessive profit, investment on transactions that is involved in uncertainty and high risk. Therefore, it should be properly named as Islamic banking and not simply non interest banking. For the model to operate effectively, the CBN should constitute the Shariah Advisory Committee (SAC) as its regulator. Else the model is destined to fail in Nigeria. In spite of the controversies and the initial challenges, Islamic banking is suitable for funding entrepreneurship and economic development in the real economy as it provides easy access to cheap source of funds. Islamic financing is increasing globally in acceptance for direct investment. Nigeria's economy should not be in isolation from other economies.

\section{REFERENCES}

1. Abdullahi, 2011CBN Issues New Guidelines For Non-Interest Banking. Central Bank of Nigeria Press Release, 21 June 2011

2. Anon, (2012), Islamic Banking in South Africa, htpp://muslimbridges.org/index.php.com downloaded 25/05/2012).

3. Anon, (2009), Vertican Paper supports Islamic Finance, France wants its share of Sharia Banking in the Brusscls Journal pasted on Thursday, 0203-2009. Published in L'osservatore Romano, the Vatican official newspapaer. http://www.liveleak.com/view?i=e80_1236894823

4. Belien, Paul, (2006), First Shariah Bank in Switzerland. In Brussels Journal, the Voice of Conservatism in Europe. www.brusselsjounal.com/node/1479. pasted from the desk of Belien 2006-10-08. Downloaded July $2^{\text {nd }}$ 2012.)

http:/abc.az/eng/news_02_12_2011_60140.html. Downloaded July 2, 2012).

5. BOFIA, (1991), Banks and Other Financial Institutions (BOFIA) Decree 1991. Lagos, 20th day of June 1991.

6. CBN Act (2007) (Central Bank of Nigeria Act 2007, in Federal Republic of Nigeria Official Gazette No. 55 Vol.94. Government notice No. 34 pp A63-91. Printed by the Federal Government Printer Lagos Nigeria FGP 95/62007/1000 (OL58). 
7. Chibuike Ugochukwu Uche (2001), Nigeria: Bank Fraud. Journal of Financial Crime, Vol. 8 Iss: 3, pp. $265-275$.

8. Eke, D.A.N (2009), Draft Framework For The Regulation And Supervision Of Non-Interest Banks In Nigeria. BSD/DIR/GEN/NIB/01/008. March 4, 2009

9. Faleel, Jamaldeen Mohamed (2010), The First Islamic in Germany. http://ifinanceexpert.files.wordpress.com/2010/01/ 9f020fc6d020878.jpg Posted on January 13, 2010. Downloadede july 2, 2012) Kzakov (2011),

10. IMF, (2009), IMF Survey Magazine: IMF Research pasted on Oct 4, 2010 www.imf.org/external/pubs/ft/survey/50/2010/res1 00410 a retrieved $15 / 5 / 2012$.

11. Kandi, Mohammed B., (2011), Between Sanusi, Critics and Non-Interest Banking. www.peoplesdaily-online.com/17688-betweensanusi-critics-and-non-interest banking. Friday, 29 July 2011 23:27 administrator.

12. Kern, Soeren (2011), Islamic "Shariah-compliant" Banking takes root in Europe. http://www.gatestoneinstitute.orgbysoerenkern Downloaded May, 19, 2011.

13. Latter, Tony, (1997), Causes and Management of Banking Crises. Hand Book No. 12. Issued by the Centre for Central Banking Studies, Bank of England London EC2R 8AH, July 1997. Bank of England 1997. ISBN 185730155 2).

14. Lawal, Yekini Olawaiye (2010), Islamic Economics the Cornerstone Of Islamic Banking. Journal of Economics and Engineering, ISSN: 2078-0346, №4, December, 2010 pp95)

15. Muhammad, Aminan, (2012) www.businessday.co29 in African Capital Market news. http://africancapitalmarketnews.com downloaded $25^{\text {th }}$ May, 2012.

16. Oriloye, Clement, (2011), Controversy Over Sharia Banking, Published on June 13, 2011 by
The

NEWS. www.thenewsafrica.com/2011/06/13/controversyover-sharia-banking

17. Parker, Mushtak (2012), UK Islamic Bank gets foothold in France. http://archive,arabnews.com. Downloaded 25/05/2012

18. Parker, Mushtak (2010) Islamic Bank enters Germany, on $25^{\text {th }}$ April 2010, www.arabnews.com/node/343397. Downloaded on 2th July 2012

19. Phillips (2012), In The CityUk Islamic Finance 2011 Report from The CityUK's UK Islamic Finance Secretariat (UKIFS) and down loaded on $8^{\text {th }}$ July 1012. www.thecityuk.com/research/ourwork/articles-2/global-islam).

20. Solagbade, Omobolaji, (2011), Non- interest banking: A Model Surrounded by Controversy, Monday $27^{\text {th }} \quad$ June 2011 http://www.nigeriabestforum.com/general topics/?p=101353) Downloaded 30th April 2012

21. Sole, Juan (2007), Islamic Finance hurdles in bid to boost West Exposure: IMF in Gulf-Times, Santhos V. Perumel, 13 August 2007).

22. Ujah, Emma, (2011), CBN rejects Al Qaeda request for banking licence. Abuja Bureau Chief, Vanguard New Paper pasted on July 4, 2011, http//www.vanguardngr.com."Islamic Banking".

23. UKIFS, (2012), Global Islamic Finance Assets reached \$1.3trillion in 2011. Published on 28/03/2012. The CityUk Islamic Finance 2011 Report from The CityUK's UK Islamic Finance Secretariat (UKIFS) and down loaded on $8^{\text {th }}$ July $1012 . \quad$ www.thecityuk.com/research/ourwork/articles-2/global-islam).

24. GIFR (2011), Global Islamic Finance Report 2011. Released May 05,2011. www.zawya.com/story/Global_Islamic_Finance_R eport_2011. Downloaded March 11, 2011. 